\title{
IMPLEMENTASI PEMBELAJARAN TAHASSUS DI MA MA'ARIF 1 JOMBANG
}

\author{
Nurul Indana \\ Prodi Pendidikan Agama Islam, STIT Al Urwatul Wutsqo Jombang \\ e-mail:nurulidana91@gmail.com \\ Noor Fatikah \\ Prodi Pendidikan Agama Islam, STIT A 1 Urwatul Wutsqo Jombang \\ e-mail:noorftikah@stituwjombang.ac.id \\ Irma Muniroh \\ Prodi Pendidikan Agama Islam, STIT Al Urwatul Wutsqo Jombang
}

\begin{abstract}
Discussions about education, it is impossible to be free from the object that is the target, namely humans. Allah SWT created humans to be the most noble creatures among the creatures He created. Each educational institution has its own learning system in achieving learning objectives. However, there are also educational institutions that have their own way of achieving learning goals, one of which is learning and memorizing Juz 30, Surat Yaasin, tahlil, namely by developing takhassus programs which can make students who have better personalities, strengthen values. the character possessed by students so that they become complete human beings, both soul, body, intellectual and personality. So, students are not only focused on general knowledge but also deepen their religious knowledge so that they are able to become human beings who have strong faith qualities. The purpose of this study is to describe the process of implementing the Tahassus program at MA Ma'arif 1 Jombang. The results showed that the Tahassus program could improve reading and writing of the Qur'an, including increasing religious knowledge and as a provision when entering the community.
\end{abstract}

Key words: Learning the Qur'an, Tahassus Program

\section{PENDAHULUAN}

Pendidikan sendiri menurut Ki Hajar Dewantara adalah daya dan upaya untuk memajukan budi pekerti (karakter, kekuatan batin), pikiran, dan jasmani anak-anak selaras dengan alam dengan masyarakatnya. ${ }^{1}$ Melalui proses tersebut diharapkan manusia dapat memahami ap aarti hakikat hidup, serta untuk apa dan bagaimana menjalankan tugas hidup dan kehidupan secara benar.

Pendidikan memiliki fungsi sebagai wadah untuk mengembangkan potensi peserta didik, dimana diharapkan peserta didik dapat memiliki kekuatan untuk

${ }^{1}$ Dedy Mulyasana, Pendidikan Bermutu dan Berdaya Saing (Bandung: Remaja Rosdakarya, 2011), Cet. 1, 3. 
menghadapi perkembangan zaman yang semakin maju, disamping itu peserta didik juga dibekali dengan ilmu pengetahuan baik agama maupun ilmu pengetahuan yang bersifat umum, serta dibekali dengan keterampilan

Hal ini sesuai dengan UU No 20 Tahun 2003 Tentang Sistem Pendidikan Nasional pada Pasal 3, yang menyebutkan bahwa pendidikan nasional berfungsi mengembangkan kemampuan dan membentuk karakter serta peradaban bangsa yang bermartabat dalam rangka mencerdaskan kehidupan bangsa. Pendidikan nasional bertujuan untuk berkembangnya potensi peserta didik agar menjadi manusia yang beriman dan bertaqwa kepada Tuhan Yang Maha Esa, berakhlak mulia, sehat, berilmu, cakap, kreatif, mandiri, dan menjadi warga negara yang demokratis serta bertanggung jawab. $^{2}$

Kutipan undang-undang no. 20 tahun 2003 tentang sistem pendidikan nasional tersebut menjelaskan pendidikan tidak hanya berperan untuk mendidik para peserta didiknya agar menjadi manusia yang cerdas, tetapi juga memiliki keharusan untuk membangun kepribadiannya agar berakhlak mulia. Saat ini, banyak kalangan menilai pendidikan di Indonesia tidak bermasalah dengan perannya dalam mencerdaskan para peserta didiknya, namun dinilai kurang berhasil dalam membangun kepribadian peserta didiknya agar berakhlak mulia.

Kehidupan Pendidikan semakin berkembang dengan lajunya zaman. Pendidikan tidak mungkin menisbikan proses globalisasi antara lain merespon proses Pendidikan dengan menciptakan sistem pendidikan yang lebih akomodatif terhadap perkembangan zaman, sehingga output nya dapat berperan secara efektif dalam kehidupan masyarakat, untuk itu pendidikan harus dirancang sedemikian rupa yang memungkinkan para peserta didik mengembangkan potensi yang dimiliki secara alami dan kreatif dalam suasana yang penuh kebebasan, kebersamaan dan tanggung jawab. ${ }^{3}$

Dalam penanaman nilai dan spiritualitas, permodelan atau pemberian teladan merupakan strategi yang biasa digunakan, khususnya di dunia pendidikan. Keteladanan yang dilakukan guru lebih tepat dalam penanaman karakter peserta didik di sekolah.

\footnotetext{
${ }^{2}$ Redaksi Sinar Grafika, UU Sistem Pendidikan Nasional (UU RI No,20 Tabun 2003) (Jakarta: Sinar Grafika, 2008), 7.

${ }^{3}$ Zamroni, Paradigma Pendidikan Masa Depan (Yogyakarta: Bigraf Publishing, 2000), 90
} 
Hal ini lantaran karakter merupakan perilaku yang muncul secara cepat, sehingga untuk dapat diinternalisasi oleh peserta didik, maka harus diteladankan bukan diajarkan.

Obyek penelitian ini adalah Madrasah Aliyah Ma'arif 1 Jombang yang bernaungan di bawah Yayasan Lembaga Pendidikan Ma'arif NU Cabang Jombang yang berlokasi di Kauman Utara Gg. I/09 Jombang. Pilihan ini didasarkan atas beberapa pertimbangan antara lain bahwa lembaga ini memiliki cara tersendiri dalam hal mempelajari dan menghafal Juz 30, surat Yaasin, tahlil yaitu dengan mengembangkan program takhassus dimana bisa menjadikan siswa-siswa yang memiliki kepribadian yang lebih baik. ${ }^{4}$ Fenomena ini menarik untuk diteliti agar diketahui bagaimana proses pelaksanaan program takhassus pada pendidikan formal sehingga bisa menjadi bahan perbandingan bagi sekolah lain yang menginginkan anak didiknya memiliki bekal ilmu yang tidak hanya bersifat umum saja melainkan dapat menghafalkan ayat-ayat Alqur'an.

Adanya program tahassus yang di kembangkan oleh MA Ma’arif 1 Jombang, menjadi tantangan tersendiri dalam mengembangkan kurikulum nya, mengingat sekolah tersebut memiliki keunggulan yangt sama, dimana dalam proses pengembangannya menurut peneliti merupakan upaya dari pengembangan mata pelajaran Pendidikan Agama Islam itu sendiri, selain itu dengan adanya program tahassus itu sendiri akan lebih menguatkan nilai-nilai karakter yang di miliki oleh siswa sehingga menjadi insan yang utuh, baik jiwa, raga, intelektual maupun kepribadian.

Pendidikan agama Islam harus bisa menginternalisasikan nilai-nilai yang terkandung dalam Alqur'an bukan hanya sekedar menyampaikan materi dan menghafalkan namun dalam kehidupan sehari-hari peserta didik bisa menjadi insan yang lebih baik. Mengingat pentingnya kurikulum dalam Pendidikan maka dalam penyusunannya pun tidak boleh sembarangan apalagi kurikulum yang didalamnya terdapat program tahassus Alqur'an yang mana dengan program tersebut diharapkan mampu menumbuhkan karakter siswa yang sadar akan agama. Kesadaran beragama adalah rasa keagamaan, pengalaman ketuhanan, keimanan, sikap dan tingkah laku keagamaan yang terorganisasi dalam sikap mental dari kepribadian. Kesadaran beragama mampu melibatkan seluruh fungsi jiwa raga manusia sehingga mampu

${ }^{4}$ Observasi di MA Ma’arif 1 Jombang, 
mencapai aspek kognitif dan psikomotor pada siswa. Dan untuk mencapai aspek tersebut perlu ditempuh dengan adanya proses belajar baik yang dilakukan di sekolah maupun di rumah.

\section{PEMBAHASAN}

\section{A. Pembelajaran}

\section{Pengertian Pembelajaran}

Pembelajaran adalah proses interaksi peserta didik dengan pendidik dan sumber belajar pada suatu lingkungan belajar. Pembelajaran merupakan bantuan yang diberikan pendidik agar dapat terjadi proses pemerolehan ilmu dan pengetahuan, penguasaan kemahiran dan tabiat, serta pembentukan sikap dan kepercayaan pada peserta didik. Dengan kata lain, pembelajaran adalah proses untuk membantu peserta didik agar dapat belajar dengan baik. Proses pembelajaran dialami sepanjang hayat seorang manusia serta dapat berlaku di manapun dan kapanpun. Pembelajaran mempunyai pengertian yang mirip dengan pengajaran, walaupun mempunyai konotasi yang berbeda.

Pembelajaran adalah pemberdayaan potensi peserta didik menjadi kompetensi. Kegiatan pemberdayaan ini tidak dapat berhasil tanpa ada orang yang membantu. Menurut Dimyati dan Mudjiono ${ }^{5}$ pembelajaran adalah kegiatan guru secara terprogram dalam desain instruksional, untuk membuat belajar secara aktif, yang menekankan pada penyediaan sumber belajar. Dalam Undang-Undang No. 20 Tahun 2003 Tentang Sistem Pendidikan Nasional pasal 1 ayat 20 dinyatakan bahwa Pembelajaran adalah Proses interaksi peserta didik dengan pendidik dan sumber belajar pada suatu lingkungan belajar. Konsep pembelajaran menurut Corey ${ }^{6}$ adalah suatu proses dimana lingkungan seseorang secara disengaja dikelola untuk memungkinkan ia turut serta dalam tingkah laku tertentu dalam kondisi-kondisi khusus atau menghasilkan respons terhadap situasi tertentu, pembelajaran merupakan subset khusus dari pendidikan. Pembelajaran mengandung arti setiap kegiatan yang dirancang untuk membantu seseorang mempelajari suatu kemampuan dan nilai yang

${ }^{5}$ Syaiful Sagala, Konsep dan Makna Pembelajaran (Bandung : Alfabeta, 2011), 62. ${ }^{6}$ Syaiful Sagala., 61. 
baru. Proses pembelajaran pada awalnya meminta guru untuk mengetahui kemampuan dasar yang dimiliki oleh siswa meliputi kemampuan dasarnya, motivasinya, latar belakang akademisnya, latar belakang ekonominya, dan lain sebagainya.kesiapan guru untuk mengenal karakteristik siswa dalam pembelajaran merupakan modal utama penyampaian bahan belajar dan menjadi indikator suksesnya pelaksanaan pembelajaran. Dapat ditarik kesimpulan bahwa Pembelajaran adalah usaha sadar dari guru untuk membuat siswa belajar, yaitu terjadinya perubahan tingkah laku pada diri siswa yang belajar, dimana perubahan itu dengan didapatkannya kemampuan baru yang berlaku dalam waktu yang relative lama dan karena adanya usaha.

\section{Tujuan Pembelajaran}

Tujuan pembelajaran merupakan salah satu aspek yang perlu diperhatikan dalam perencanaan pembelajaran. Karena tujuan merupakan sesuatu yang dicarai dalam pembelajaran. Tujuan pembelajaran merupakan suatu perulaku yang hendak dicapai atau dapat dikerjakan oleh peserta didik pada tingkat dan kondisi tertentu. Tujuan pembelajaran lebih diarahkan kepada taskonomi bloom an krathwohl. Mereka membagi tujuan pembelajaran menjadi tiga kawasan yaitu:

a) Kawasan kognitif: kawasan kognitif erat kaitannya dengan segi proses mental yang diawali dari tingkat pengetahuan hingga evaluasi.

b) Kawasan afektif: kawasan afektif erat kaitannya dengan sikap, nilai-nilai keterkaitan, penghargaan, dan penyesuaian perasan social.

c) Kawasan psikomotor: kawasan psikomotor terkait dengan keterampilan yang bersifat manual atau motorik

\section{B. Tahassus}

Tahassus berasal dari bahasa arab خصوصـ yang memiliki makna mengkhususkan atau ص اخت yang berarti khas atau tertentu, dan تخصص yang penulis maksud ialah sesuatu yang dikhususkan atau difokuskan. ${ }^{7}$ Dalam penelitian ini tahassus yang dimaksud ialah mata pelajaran khusus (pendalaman agama) yang diajaran di madrasah sebagai ciri khas dari madrasah tersebut.

${ }^{7}$ Ahmad Warson Munawir, Almunawir Kamus Bahasa Arab-Indonesia(Surabaya: Progresif,1999), 381. 
Kurikulum tahasus adalah suatu pedoman khusus yang dibuat oleh lembaga pendidikan sendiri sebagai ciri khas dari lembaga tersebut untuk membedakan dengan lembaga pendidikan yang lain. Kurikulum tahasus yang dibuat lembaga pendidikan yang bercirikan ke-Islaman biasanya cenderung mengedepankan mata pelajaran khusus pendidikan agama Islam.

Secara khusus pendidikan agama Islam merupakan bagian integral dari program pengajaran setiap jenjang lembaga pendidikan (SD/ MI, SMP/ MTs, SMA/ MA) serta merupakan usaha bimbingan dan pembinaan guru terhadap peserta didik dalam memahami, menghayati, dan mengamalkan ajaran agama Islam sehingga menjadi manusia yang Taqwa dan warga negara yang baik. ${ }^{8}$

Diberikannya mata pelajaran PAI bertujuan untuk terbentuknya peserta didik yang beriman dan bertakwa kepada Allah SWT, berbudi pekerti yang luhur (berakhlak yang mulia), dan memiliki pengetahuan yang cukup tentang Islam, terutama sumber ajaran dan sendi-sendi Islam lainnya, sehingga dapat dijadikan bekal untuk mempelajari berbagai bidang ilmu atau mata pelajaran tanpa harus terbawa oleh pengaruh-pengaruh negatif yang mungkin ditimbulkan oleh ilmu dan mata pelajaran tersebut.

Dengan demikian, ciri khas agama Islam ditandai dengan adanya kegiatan yaitu semakin meningkatnya program-program pendidikan agama secara optimal, antara lain melalui penambahan jam pelajaran pendidikan agama. Semakin memungkinkan terjadinya integrasi pendidikan melalui program keterpaduan serta keterkaitan antara konsep (teori) ilmu pengetahuan (sains) dengan ajaran agama. Semakin terwujudnya suasana keagamaan yang kondusif yang dicerminkan dalam kehidupan ibadah dalam amalan dan perilaku sehari-hari. Semakin terwujudnya rasa untuk mengagungkan kebesaran Allah, melaksanakan syiar dan ajaran agamanya serta menjalankan shalat jama'ah di sekolah. Semakin meningkatnya kesadaran memuliakan agama Allah, mencintai orang tua dan menghormati gurunya serta mengamalkan amal shaleh dalam arti yang seluas-luasnya.

Semakin meluasnya kegiatan ekstra kurikuler yang menitik beratkan kepada kegiatan keagamaan sehingga mampu mengembangkan kepribadian siswa

8Zuhairini, dkk, Metodologi Pendidikan Agama, (Solo: Ramadhani, 1993), 54. 
secara utuh, baik pengembangan sikap, perilaku dan pola pikir, maupun dalam rangka memantapkan pelaksanaan dan pengamalan ajaran agama Islam guna memperoleh keridhaan Allah SWT. Semakin terpeliharanya dalam pelaksanaan ajaran Islam di sekolah, baik tentang kebersihan, ketertiban, keindahan, keimanan maupun sikap kekeluargaan, harga diri dan semangat kebersamaan.

Sebagai upaya untuk mewujudkan ciri khas seperti dimaksudkan diperlukan penciptaan suasana keagamaan di sekolah, suasana kehidupan keagamaan di sekolah sebagai lingkungan yang kondusif dalam proses pendidikan yang dijalankan. ${ }^{9}$ Kurikulum tahasus ini sebagai perangkat rencana dan pengaturan mengenai tujuan, isi, dan bahan pelajaran pendidikan agama Islam serta cara yang digunakan sebagai pedoman penyelenggaraan kegiatan pembelajaran yang telah disusun secara khusus oleh sekolah untuk mencapai tujuan pendidikan di sekolah tertentu

\section{ANALISIS}

A. Proses Pelaksanaan Pembelajaran Al-Qur'an Melalui Program Tahassus Di MA Ma'arif 1 Jombang.

Proses pelaksanaan pembelajaran Alqur'an melalui program tahassus yaitu dilakukan adanya persiapan, persiapan yang digunakan guru sebelum melaksanakan pembelajaran tahassus adalah menyiapkan peserta didik. Guru memberikan pendampingan terlebih dahulu kepada peserta didik terkait pembelajaran tahassus seperti memberikan materi serta pengetahuan baca tulis qur'an agar siswa tidak mengalami kesulitan dalam menghafal dan mempraktekkan pembelajaran tahassus nanti. Setelah itu peserta didik melaksanakan program tahassus meliputi hafalan (Juz Amma, wirid, tahlil, asmaul husna, istighasah), baca kitab, praktik ibadah. Selain dengan pembelajaran tahassus, disekolah juga menerapkan kebiasaan-kebiasaan baik seperti sholat dhuha berjamaah dan berdoa bersama sebelum masuk kelas. Adanya program tahassus di sekolah tersebut adalah tak lain untuk menambah pengetahuan keagamaan peserta didik, dan sebagai bekal siswa nanti ketika terjun dalam masyarakat.

${ }^{9}$ Abdul Rachman Shaleh, Madrasah dan Pendidikan Anak Bangsa Visi, Misi dan Aksi, (Jakarta: Raja Grafindo Persada, 2004), 259- 260. 
Berdasarkan hasil wawancara tersebut dapat disimpulkan bahwa dengan program tahassus yang diterapkan dalam sekolah itu sangat bagus dalam meningkatkan baca tulis al-qur'an peserta didik karena dengan cara itu pengetahuan keagamaan peserta didik lebih luas dan kebiasan-kebiasaan baik yang diterapkan disekolah juga dapat diterapkan dimana pun mereka berada.

Kurikulum tahasus adalah suatu pedoman khusus yang dibuat oleh lembaga pendidikan sendiri sebagai ciri khas dari lembaga tersebut untuk membedakan dengan lembaga pendidikan yang lain. Kurikulum tahasus yang dibuat lembaga pendidikan yang bercirikan ke-Islaman biasanya cenderung mengedepankan mata pelajaran khusus pendidikan agama Islam.

Secara khusus pendidikan agama Islam merupakan bagian integral dari program pengajaran setiap jenjang lembaga pendidikan (SD/ MI, SMP/ MTs, SMA/ MA) serta merupakan usaha bimbingan dan pembinaan guru terhadap peserta didik dalam memahami, menghayati, dan mengamalkan ajaran agama Islam sehingga menjadi manusia yang Taqwa dan warga negara yang baik. ${ }^{10}$ Persiapan yang dilakukan guru untuk melaksanakan pembelajaran Alqur'an dalam program tahassus adalah :

1) Guru memberikan kebiasaan-kebiasaan baik seperti berdoa pagi sebelum masuk kelas dan sholat dhuha berjamaah

2) Guru memberikan pengetahuan baca tulis arab, penjelasan serta pendampingan kepada peserta didik terkait pembelajaran tahassus. Karena penting sekali bagi guru untuk mengajarkan baca tulis arab sebelum peserta didik disuruh menghafalkan karena akan sangat sulit bagi siswa untuk menghafalkan jika belum bisa membaca tulis Arab.

\section{B. Faktor Pendukung Dan Penghambat Yang Dihadapi Guru PAI Dalam} Pembelajaran Alqur'an Melalui Program Tahassus Di MA Ma'arif 1 Jombang.

1) Faktor Pendukung :

a) Faktor Semangatnya Peserta Didik

10 Zuhairini, dkk. Metodologi Pendidikan Agama. (Solo: Ramadhani. 1993). 54 
Semangat peserta didik bisa menjadi faktor pendukung bagi dirinya sendiri. Semangat nya yang tinggi dalam melaksanakan tugasnya akan dapat memudahkan proses pembelajaran dengan baik. Peserta didik yang semangat dan aktif dalam segala kegiatan yang positif maka akan lebih mudah untuk didisiplinkan. Kesadaran nya sebagai peserta didik maka dia harus mentaati peraturan sekolah dan kesadarannya sebagai umat beragama maka dia akan melaksanakan apa yang menjadi tugasnya sebagai umat yang beragama yaitu patuh terhadap ajaran Allah dan larangannya. Jadi, diri sendirilah yang harus bisa memotivasi diri untuk semangat dalam mencari ilmu demi terwujudnya cita-cita yang kita inginkan.

b) Faktor Pendidik Yang Menyenangkan

Semangat pendidik juga sangat berpengaruh pada semangat peserta didik. Dimana metode pendidik dalam menyampaikan materi itu menyenangkan dan tidak membosankan. Selain menyampaikan materi, pendidik juga memberi motivasi pada mereka agar mereka lebih semangat dan butuh kesabaran yang besar dalam menghadapi peserta didik. Karena pendidik yang menyenangkan akan membuat peserta didik merasa senang dan nyaman ketika diajar.

c) Sarana dan Prasarana

Sarana dan prasarana merupakan salah satu factor pendukung bagi berjalannya suatu pembelajaran. Selain rasa nyaman peserta didik juga difasilitasi kebutuhannya seperti buku-buku pembelajaran, peralatan kelas yang lengkap dan nyaman sehingga dapat menumbuhkan semangat siswa dan tidak mudah bosan.

2) Faktor Penghambat

a) Pengetahuan Agama Peserta Didik

Rata-rata faktor penghambatnya adalah minimnya pengetahuan agama peserta didik yang menjadi pengaruh bagi mereka dalam melaksanakan pembelajaran tahassus. Selain tidak bisa baca tulis Alqur'an, kebanyakan dari lulusan sekolah negeri juga menjadi pengaruh bagi mereka karena bagi mereka baca tulis Alqur'an saja sulit apalagi menghafalkan. 
Dominan anak yang lulusan sekolah negeri mereka tidak bisa baca tulis Alqur'an/pemahaman agamanya sangat minim sekali.

b) Suasana

Suasana kelas yang sepi juga dapat menjadi pengaruh semangat belajar peserta didik karena suasana yang membosankan dapat merubah siswa menjadi ngantuk, kurang semangat atau bahkan siswa memilih ramai sehingga pembelajaran pun tidak bisa berjalan dengan baik.

c) Belum adanya Buku panduan pembelajaran tahassus yang baku

d) Kurangnya motivasi dari keluarga

Orang tua adalah factor utama bagi anak, karena orang tua itu lembaga utama bagi anaknya sebelum mengenal sekolah. Selain tidak adanya motivasi dan dukungan dari orang tua, tidak jarang pula orang tua tidak mau tahu pendidikan anaknya, tidak pernah ditanyai bagaimana sekolahnya, tidak mengingatkan untuk mempelajari materi-materi yang dipelajari disekolah dll. Karena rata-rata orang tua disibukkan dengan pekerjaan sendiri. Jadi perhatian untuk anaknya sangat minim sekali.

Kondisi lingkungan keluarga yang baik, merupakan lingkungan pendidikan yang paling berpengaruh dibandingkan yang lain. Lingkungan keluarga sangat berpengaruh terhadap keberhasilan peserta didik untuk mendapatkan hasil belajar yang baik. Hal ini di perkuat oleh teori yaitu:

"Situasi keluarga (ayah, ibu, saudara, adik, kakak, serta famili) sangat berpengaruh terhadap keberhasilan anak dalam keluarga, pendidikan orang tua, status ekonomi, rumah kediaman, persentase hubungan orang tua, perkataan, dan bimbingan orang tua, mempengaruhi pencapaian hasil belajar anak".

Seorang anak sangat membutuhkan dorongan dan pengertian orang tua. Bila anak sedang belajar jangan diganggu dengan tugas-tugas di rumah. Kadang-kadang orang tua cenderung memberikan respon yang baik terhadap anak sehingga prestasinya menjadi baik, sebaliknya, jika lingkungan keluarg tidak baik, kecenderungan besar akan berdampak negatif bagi perkembangan peserta didik dan prestasi belajarnya. mengalami lemah semangat, orang tua wajib memberi pengertian dan 
mendorongnya, membantu sedapat mungkin kesulitan yang dialami anak disekolah. Kalau perlu menghubungi guru anaknya, untuk mengetahui perkembangannya. Lingkungan keluarga adalah tempat anak-anak belajar tumbuh dan berkembang menuju kedewasaan. Keluarga merupakan lembaga pertama dimana anak mengenal lingkungan masyarakatnya dan menyatakan diri sebagai makhluk sosial. Di dalam keluarga kepribadian anak akan terbentuk karena daya interaksi yang inti antara anggota keluarga terutama orang tua (ayah dan ibu).

\section{KESIMPULAN}

Pembelajaran tahassus memiliki dua model pembelajaran yakni ada yang klasikal ada yang hafalan. Pembelajaran klasikal seperti materi aswaja dilaksanakan setiap 1 minggu sekali dan setiap kelas berbeda-beda hari sesuai dengan jadwal pelajaran masing-masing. Untuk hafalan (juz Amma, wirid, tahlil, asmaul husna, istighosah) baca kitab dan praktik ibadah tidak hanya dilaksanakan pada saat jam pelajarannya saja tetapi juga memanfaatkan jam kosong ketika guru mata pelajaran lain tidak bisa hadir, dan disetorkan H-7 sebelum ujian karena sudah menjadi syarat mutlak bagi siswa untuk menyetorkan hafalan-hafalan yang telah ditentukan oleh guru untuk mengikuti ujian. Faktor pendukung: semangatnya peserta didik, faktor pendidik yang menyenangkan, sarana dan prasarana. Faktor penghambat: pengetahuan agama peserta didik, suasana, belum adanya buku panduan pembelajaran tahassus yang baku, dan kurangnya motivasi dari keluarga.

\section{DAFTAR PUSTAKA}

Mulyasana, Dedy, Pendidikan Bermutu dan Berdaya Saing, Bandung: Remaja Rosdakarya, 2011.

Redaksi Sinar Grafika, UU Sistem Pendidikan Nasional (UU RI No,20 Tabun 2003), Jakarta: Sinar Grafika, 2008.

Zamroni, Paradigma Pendidikan Masa Depan, Yogyakarta: Bigraf Publishing, 2000.

Sagala, Syaiful, Konsep dan Makna Pembelajaran, Bandung : Alfabeta, 2011. 
Warson, Ahmad, Munawir,Almunawir Kamus Bahasa Arab-Indonesia, Surabaya: Progresif,1999.

Zuhairini, dkk, Metodologi Pendidikan Agama, Solo: Ramadhani, 1993.

Rachman Shaleh, Abdul, Madrasah dan Pendidikan Anak Bangsa Visi, Misi dan Aksi, Jakarta: Raja Grafindo Persada, 2004. 